\title{
Education and Sustainability: A Pedagogical Experience for the Interaction with the Brazilian Semiariad Region
}

\author{
Cleire Lima da Costa Falcão', José Falcão Sobrinho², Francisco Elitom Rodrigues da Silva ${ }^{3}$, \\ Maria Luisa Ximenes Castelo Branco ${ }^{3}$, José Marcelo Soares de Oliveira ${ }^{3}$
}

${ }^{1}$ State University of Ceará, Fortaleza, Brazil

${ }^{2}$ StateUniversity Vale do Acaraú (UVA), Sobral, Brazil

${ }^{3}$ Academic Master in Geography (MAG/UVA)

Email: falcao.sobral@gmail.com

How to cite this paper: da Costa Falcão, C. L., Sobrinho, J. F., da Silva, F. E. R., Branco, M. L. X. C., \& de Oliveira, J. M. S. (2019). Education and Sustainability: A Pedagogical Experience for the Interaction with the Brazilian Semiariad Region. Creative Education, 10, 505-516.

https://doi.org/10.4236/ce.2019.103036

Received: January 24, 2019

Accepted: March 1, 2019

Published: March 4, 2019

Copyright () 2019 by author(s) and Scientific Research Publishing Inc. This work is licensed under the Creative Commons Attribution International License (CC BY 4.0).

http://creativecommons.org/licenses/by/4.0/

\section{(c) (i) Open Access}

\begin{abstract}
The purpose of this article was to present the results and discussions of an action research developed by teachers and high school students in a public school in the Sobral-CE municipality, Brazil's semi-arid region, where they elaborated and developed an interdisciplinary project aiming to seek the development of new sustainable methods and technologies for the treatment and reuse of domestic effluents and also to avoid wasting drip-treated water on school taps, drinking fountains, sinks and air-conditioning units. The starting point for the project was the group's concern about the wastefulness observed in the school environment and the awareness of issues related to the limitations of access to water by humanity in recent times. Thus, the main purpose of this project was the development of a practical environmental education capable of contributing effectively to the living conditions improvement in the semi-arid environment, based on the case study, having the school space as a research laboratory, proposing new educational challenges for teachers and learners in the another posture constitution of the same in relation to nature and its resources; based on the study of concrete cases of the daily life of said actors, thus fostering students' interest in scientific research. To do so, it started with TGS as the main methodological resource, whose course followed the steps of a quantitative research, whose results ratified the project initial hypotheses, showing that it was possible to develop an interdisciplinary environmental education in a practical and attractive way for students from simple ideas and to insert the student in the universe of scientific research still in basic education.
\end{abstract}




\section{Keywords}

Interaction with the Semi-Arid, Environmental Education, Sustainability, Interdisciplinarity

\section{Introduction}

We can consider contextualized education as being an integral part of a whole complex and interdependent system that is society. We then proceed to analyze this event that aims at horizontal education and intermittent dialogues establishment either in a playful way (Falcao Sobrinho et al., 2017; Costa Falcão et al., 2018), application of educational tools (Silva et al., 2017) or case studies (Falcao Sobrinho et al., 2018). Contextualizing education, meaning in detail, promotes debates that relate to lived reality and knowledge elaborated from premises that corroborate to produce knowledge that exalts the students themselves (Quintella Baptista \& Campos, 2013).

About the education on the semiarid region, the education has been a challenge due to many economic and political issues faced by the population, even teaching in traditional forms had been denied to the sertanejo population and they had perpetuated this perspective of belonging to a class surrounded only by folklore, myths and superstitions. The region population are the people who live in the Brazilian semiarid region also known as backcountry people. The studied region exudes very characteristic cultural and behavioral aspects, one of the examples found in cordel literature, which could be better used by official education programs. Cordel is a Brazilian traditional type of literature created by the backcountry population.

In addition, regarding the importance of the basic school, in this process, we have to refer to Paulo Freire, in "Theology of Liberation", using everyday objects of the sertanejo reality (Quintella Baptista \& Campos, 2013). Reflecting better, we visualize that contextual education is not restricted only to rural areas, but also to any place that requires deepening of reality, necessary work in front of the students needs, farmers, or other sectors of society.

In this sense, regarding education contextualized in the semi-arid, it is related to Environmental Education.

Through the Environmental Education we work in the school the knowledge of the reality, the study of the subjects from the reality and, in the process of technical assistance in the communities, the concrete life of the people: the abstraction of water, the rational use of the waters, water care, polyculture, natural and non-poisonous fertilization, creole seeds, agroecology and, mainly, farmers as subjects of their semiarid transformation hikes (Quintella Baptista \& Campos, 2013: p. 110).

Even if the subject is not treated explicitly, it is introduced through actions and instigates the re-reading of abandoned rural practices due to the public policies of "drought combat", considerably increasing the self-esteem of the farmer. 
Regarding the treatment given to the Environmental Education, in these documents, according to Brasil Ministério da Educação e do Desporto/Secretaria de Educação Fundamental (1998), the environmental theme has a transversal character, so it can and should be incorporated in an interdisciplinary way. It involves urgent social anxieties, which need adaptations taking into account regional differences.

In view of the problems highlighted in the coexistence with the semi-arid region, it is necessary to approach intrinsic aspects of the relationship of Environmental Education aligned with a perspective of addressing the more specific problems of our region. In this context, the practices of the human being towards nature permeate the estrangement and disintegration, allied to exacerbated consumerism (Guimarães, 1995).

However, the education role in this matter lies in the participatory action of all those involved in the educational process. The educator's job is not only to dissect isolated incorrect attitudes but, above all, to clarify the alarmist dramatics to which the theme can be approached (Guimarães, 1995). Therefore, Guimarães (1995) suggests in his reflection on education and the environment and our contextualization with lived reality, to propose an integrative basis between nature and man in the Semi-Arid, excluding the term "domination" of this relation.

A reading related to space is carried out through research in various sources of scientific and/or empirical origin, such as the production of records in the field of observation and interviews in different spaces. In this way, the study of the environment is a teaching methodology that can be inserted in an interdisciplinary way; this one intends to unravel the complexity of a certain dynamic space, that is, in constant transformation.

Environmental Education is therefore one of the most important stages of the study of the environment, with fieldwork as the main factor in the perspective of widening the gaze in the studied environment, the various ways of conceiving the place. From this, from these distinct realities, knowledge is produced that is not present in textbooks, but practice conditions such knowledge.

In the current of globalization scenario, it is observed that population growth and the rapid advance of urban centers bring up an increasing concern with water resources and their adequate management due to the increased pollution from the main sources accessible to most populations, which are: lakes and urban lagoons. Since about one liter of water consumed in urban dwellings, on average $80 \%$ is transformed into sewage, the destination of which, usually without any previous treatment, is the discharge into the nearest rivers or ponds through sewage networks.

However, it is known that the water problem in this current global context lies not only in its scarcity. This is, in turn, only one of the consequences of a set of factors that have been contributing in recent times to the reduction of supply and the water quality accessible to mankind, among them, the lack of environmental awareness by part of the vast majority of people in relation to the correct use of water resources. In this context, it is believed that school education, when 
well applied, is an important tool capable of contributing substantially to the formation of a new awareness of the people in relation to the environment and natural resources, especially water, from small initiatives that were consolidated in the execution of an interdisciplinary pedagogical project developed at the Dom José Tupinambá da Frota State Middle and High School, in Sobral-CE between 2013 and 2015. This project is considered a successful experience by the school community in the environmental education and development to scientific research area at school.

The project is justified, given the facts presented, for its importance as an experimental practices pilot project in the environmental education and promotion of scientific research, in the elucidation of new researchers in the scope of basic education.

The theme that generates this research action is a factor of high concern for authorities and international bodies such as the UN, for example, whose current situation of humanity in relation to natural resources, especially water, presupposes an announced tragedy regarding access to drinking water humanity in the near future. Therefore, it is necessary and urgent to develop actions that aim to promote environmental education in a practical way, providing the interdisciplinarity of the various areas of knowledge, capable of developing simpler and more accessible methods and technologies, which guarantees greater interactivity of the individuals among themselves and between them and nature from school education as a primary factor in the formulation of new positions of the individual in relation to the environment.

Based on this perspective, this school project had as main proposal the involvement of the whole school community in the formation of a new posture of individuals in relation to nature and the preservation of their natural resources, in this case, with emphasis on water as an element of the actions of the project, so that one can think of nature as a whole, whose elements interconnect one another in a complex way, by successive and reciprocal exchanges of matter and energy, constituting a set of connected and interdependent elements between itself in the constitution of the whole. This fact presupposes the understanding of man as a constituent element of this whole, thus, the same must interact in tune with the other elements of the environment, in order to provide a natural balance. Such perception presupposes the General System Theory use as the main methodological resource in this action-research.

According to Lopes et al. (2015), the TGS was proposed by the Austrian biologist Ludwig von Bertalanffy (with his works published between 1950 and 1968), with the interdisciplinary purpose to transcend the problems unique to each science and to provide general principles and models for all the sciences involved, so that the discoveries made in each could be used by the others. Thus, TGS proposes the existence of a reciprocal dependence between all the sciences and an urgent need for its integration, observed in the Falcão Sobrinho et al. (2017) study.

The aforementioned action research directly involved 40 (forty) students of 
the three classes of the first year of high school of the referred basic education school, who acted as researchers and monitors practical actions developed with the other students of the school; 06 (six) teachers from the areas: Philosophy, Geography, Biology, Chemistry and Portuguese Language from which subject, who acted as coordinators and also guiding the project. Indirectly, the project involved the other members of the school community, parents and other residents, technicians from the Municipal Environmental Authority-AMMA and the Research and Extension Laboratory in the Semi-Arid-UVA.

During the project execution, the students participated in several practical activities and had the opportunity to interact with several environment professionals through lectures, workshops and field classes, as well as participation in local and regional scientific fairs, as shown in Figure 1.

In these external activities, students learned more about the importance of water resources preservation, their rational use and the care that each one must have individually to guarantee collective access to this good. They also learned sustainable techniques from successful experiences presented to them during field lessons by teachers and from contact with other cultures, such as the experience of visiting the Tremembé community, where the students dialogued with community residents and heard their reports of experiences about the subject.
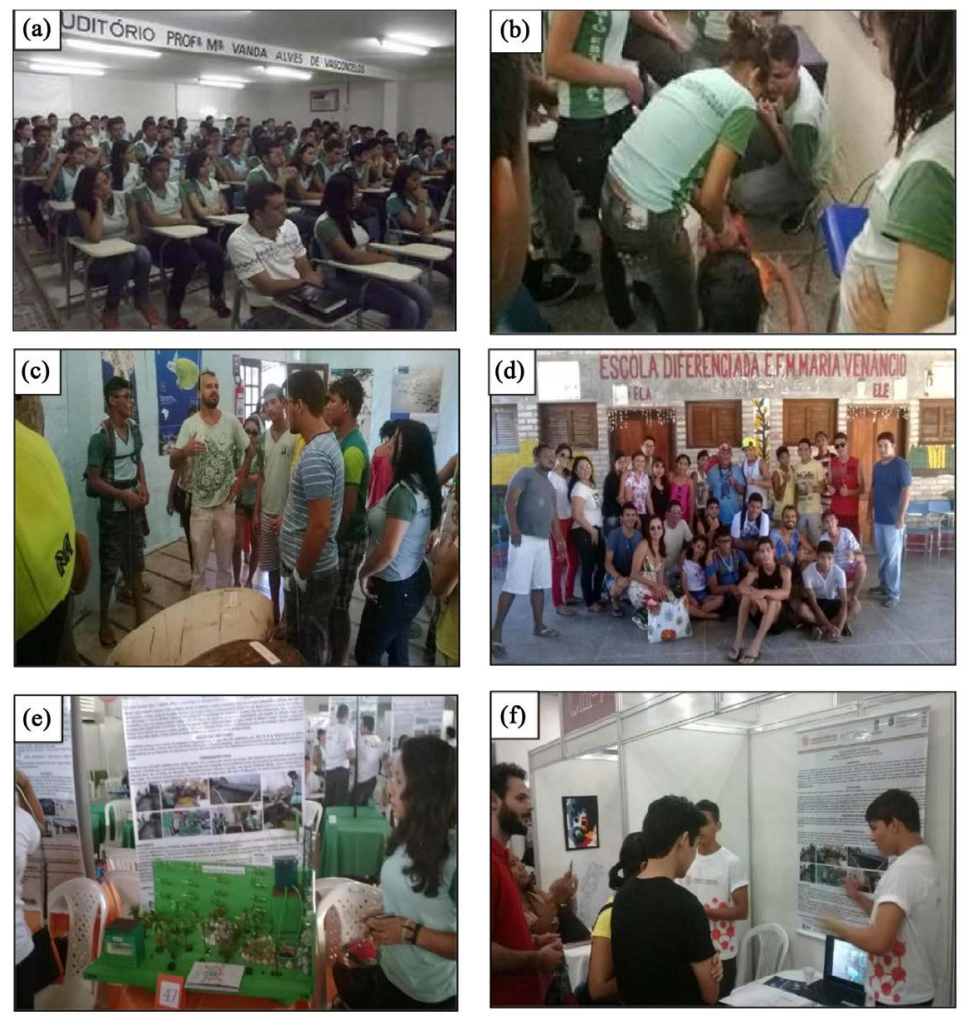

Figure 1. Project actions and participation in events. (a) Lecture on sustainable consumption in the school auditorium; (b) Workshop for the equipment construction for collection and treatment of effluents; (c) Visit to the TAMAR project-Itarema; (d) Visit to the Tremembé, Itarema-CE community; (e) Participation in a regional scientific fair; (f) Participation in a national scientific fair. Source: Author's file. 


\section{Methodology}

The implementation and execution of this interdisciplinary project followed the following methodological course: bibliographical survey, case study, field research, working groups formation, presentation of the proposal and results to the school community through lectures and environmental events held in the school itself, such as environmental week, an activity with the purpose of discussing environmental issues with the school community and electing representatives to represent it at other events of the same nature at the state and national levels, see following images.

After a bibliographical survey and the fundamental aims definition of the research, the group, under the guidance of the aforementioned teachers, was divided into work teams, each team being under the guidance of a teacher, who coordinated the research actions so that the same were developed as practical classes associated with the programmatic contents of the textbook, in which the students related theory and practice in the teaching and learning process, while doing science at the same time.

Thus, these groups developed their research actions based on a case study, which themselves developed actions of observation, measurement, variables annotation about the object, associating the fieldwork with laboratory activities.

In these activities, the students investigated the final destination of the school's sewage (domestic sewage) and the dripping waste measurement: on taps (toilets and drinking fountains) and air-conditioning units (ten units installed). It was verified with this that the school lost about 200 liters of water every three hours per school day. From this initial survey, the research group started to discuss the subject with the other students and with the school community at occasional moments such as lectures, environmental events, or in the classroom itself by the teachers of the mentioned disciplines, in an interdisciplinary way with the of textbook respective contents (Figure 2).

With the consolidation of the project proposal and its well-defined objectives: 1) General aim - to promote individuals environmental awareness through school education; 2) Specific aim-to promote students' interest in scientific research, to develop new techniques and sustainable technologies for the rational water consumption, to propose the interdisciplinarity of the school various knowledge areas in the new knowledge constitution in relation to nature and the coexistence with the semi-arid as a methodological resource applicable in basic education.

We began to research consolidated sustainable technologies examples applied in the treatment and effluents utilization in other realities and, from then on, through tests carried out by the students, was adapting some techniques in the development of new sustainable technologies according to the reality of the northeastern semi-arid region and the project objectives.

After testing various techniques and suitable technologies for the treatment and domestic effluents reuse, studies have developed a water treatment system 
using recycling techniques known as wetlands, techniques used in the USA and in European countries as a wastewater treatment system that uses aquatic plants, whose roots of these plants extract the nutrients they need while filtering pollutants from the water. It consists of the system constitution for capturing and storing effluent (only gray water), effluent from the bath and sinks of the bathroom and kitchen in a collection tank, where the basic effluent treatment consists of simple filtration, aeration and biological treatment with the use of fish and aquatic plants in the collecting tank.

After this initial treatment, water is pumped into a raised box through an electric pump and then distributed by gravity to water the school's garden and vertical garden using a low-pressure irrigation system. Thus, the collecting process, treating and reusing the effluent involves a set of other elements that are aggregated in the process, fundamental instruments that constitute such a sustainable structure, as shown in the following images (Figure 3 ).
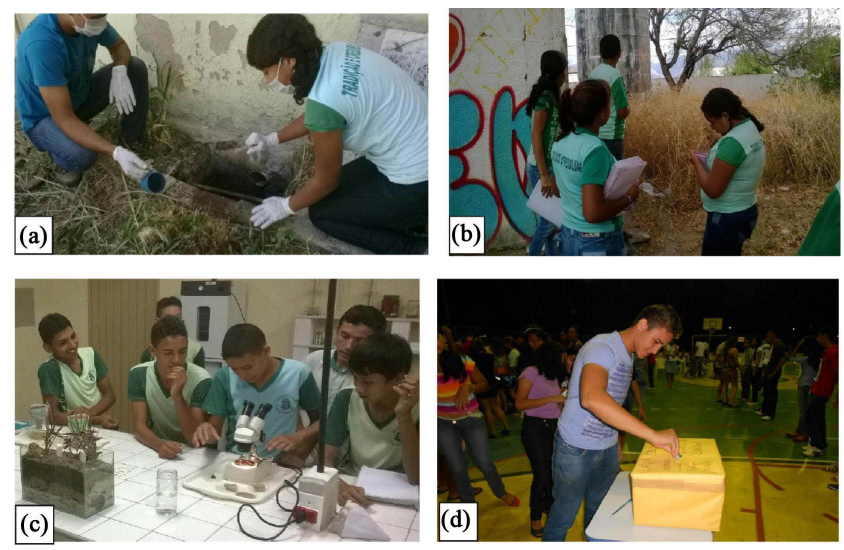

Figure 2. Practical activities. (a) Development of case studies and environmental event in school; (b) Field class; (c) Laboratory analysis; (d) Realization of the environmental forum in the school. Source: Author's file.
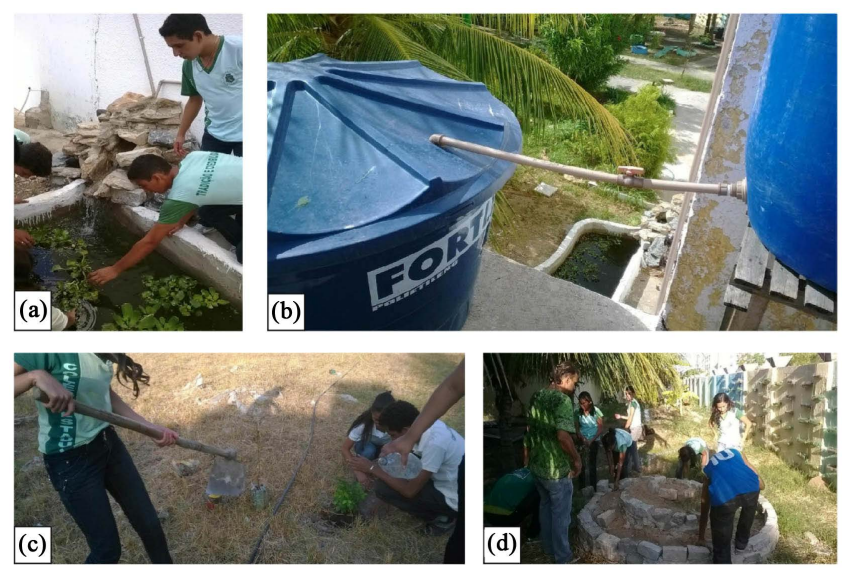

Figure 3. Practical actions. (a) Effluent collection and treatment tank; (b) Secondary filter and treated effluent storage box; (c) Irrigation system preparation and seedling planting; (d) A spiral of herbs construction and vertical garden with pet bottles. Source: Author's file. 


\section{Theoretical Reference}

Faced to the environmental problems present in our daily life and the new challenges of educating ourselves in a global context in which consumerism makes people oblivious to environmental issues, school becomes the main instrument for transforming this reality. Thus, it is understood that the school environment is the place to develop new ideas and a critical sense of reality, a place for the formation of autonomous individuals, capable of recognizing their own habitat and their role in it. Thus, teachers as important elements in the political and social formation of individuals can form a foundation based on the practical action of citizenship, encouraging their students to believe in their own potential to combat the problems closest to themselves.

Facing these issues Minc (2005) states: Throughout the ages the perception, the object and the activism in the ecological area have been transformed. From the animal species and forests defense, the environmentalism has reached the productive systems, urban life and began to cover issues such as health, technologies, consumer and citizen rights. Schools should function as poles that radiate ecological awareness, involving families and the community. Schools can defend lakes, reforest slopes, house recycling centers.

It is understood, therefore, that the environment includes all factors that directly affect the behavior of a living being or species including light, air, water, soil and the living beings themselves living in the same environment. According to Emídioapud Lima (2007):

Society as a whole is responsible for preserving the environment, so we must act in the best way possible not to modify it in a negative way, as this will have consequences for the quality of life of current and future generations, understanding that the environment originally conceived as the physical and chemical conditions, together with the ecosystems of the natural world, and which is the habitat of man, is also, on the other hand, a reality with a dimension of time and space. This reality can be both historical (from the point of view of the process of transformation of the structural and natural aspects of that environment by man himself, because of his activities) and social (insofar as man lives and organizes himself in society, producing goods and services designed to meet the needs and survival of their species (EMÍDIO apud, LIMA, 2007: p. 127).

In this perspective, it is understood that environmental education is both an information and formation process of individuals, aiming at improving their quality of life and that of all community members to which they belong.

The federal legislation that establishes the National Environmental Education Policy defines as education "the processes through which the individual and the community construct social values, knowledge, skills, attitudes and skills aimed at the environment conservation, as well as the common use of people, essential to the healthy quality of life and its sustainability".

In the 225 Article of the 1988 Federal Constitution, the following approach exists: Everyone has the right to an ecologically balanced environment, a com- 
mon use of the people is essential to the quality of life by imposing on the public power and to the community the duty to defend it and preserve it for present and future generations (Brazil, 1988).

It is understood that human society cannot be sustained without drinking water, clean air, and fertile soil and without a mild climate. Many people, however, have not understood this yet. In developing their socio-economic activities, they destroy in an irrational way the bases of their own support. They do not realize that they depend on an ecological basis for their lives and that of their descendants. They live as if they were the last generation on Earth.

It is important to mention that the study of environmental issues, their causes and consequences should not be restricted only to the classroom, between the teacher of the area and his students. It is understood that human society cannot be sustained without drinking water, clean air, fertile soil and without a mild climate. Many people, however, have not understood this yet. In developing their socio-economic activities, they destroy in an irrational way the bases of their own support. They do not realize that they depend on an ecological basis for their lives and that of their descendants. They live as if they were the last generation on Earth.

It is important to mention that the study of environmental issues, their causes and consequences should not be restricted only to the classroom, between the teacher of the area and his students, there must therefore be an interdisciplinarity, teacher training and work together of all those who are part of the school, so that students can develop, in addition to the awareness of environmental preservation, the importance of group work and respect for all who are part of the school group.

According to Lindner (2012), Environmental Education goes far beyond merely permeating scientific and academic doing; it enables a new philosophy of life. It is necessary to seek means so that the activities exercised in the school apparatus are not something sporadic, but that a relationship of respect and harmony is created between the individual, the collective and the environment. Therefore there must be an interdisciplinarity, teacher training and work together of all those who are part of the school, so that students can develop, in addition to the awareness of environmental preservation, the importance of group work and respect for all who are part of the school group.

\section{Results and Discussions}

The results of this project were considered very satisfactory for the school community as a whole. In addition to the development of a simple and low-cost sustainable treatment system, the project has also effectively contributed to the closer ties between school and university and institutions related to the environment and research through collaborative partnerships in practical activities in the society and in the development of laboratory activities.

Such partnerships in the development of project activities allowed students to 
discover the universe of scientific research, arousing in them the desire to join the university, especially in the areas related to action research developed at the mentioned school. Within the scope of pedagogical activities, according to the teachers directly involved, there was a substantial improvement in the students' learning in their respective disciplines.

As for the school's external participation in scientific fairs, there was a substantial increase in the number of participations and works presented in the environmental or related area in the period between 2013 and 2015, with the school for the first time, reaching the state stage of the fair in 2014, with the presentation of the work developed in the school, besides the participation in several fairs and regional scientific meetings, of which the project was winner more than once in the environmental and sustainability theme.

From the academic point of view, the gains for the participants have been great, from the publication of scientific articles in magazines and books to the approval of students in undergraduate courses at local higher level public institutions, IFCE, UVA and UFC, in the areas related to involved in the school project; the approval of professors in Latu Sensu (specialization in environmental management-IFCE) and strict Sensu (Academic Master's Degree in Geography-UVA) postgraduate programs.

From a pedagogical point of view, the project developed by these public school students contributed to the development of new teaching methodologies in basic education. The equipment built by the students in the execution of the project began to integrate the pedagogical resources of the school as experimental elements used in the pedagogical activities by the various areas of school knowledge, where it is possible to promote a practical and interdisciplinary environmental education with the different subjects that make up the school curriculum in addition to providing a significant saving in the daily consumption of water consumed in school, promoting scientific research in the school environment and contributing to the development of a new attitude of the school community towards water and its uses.

\section{Final Considerations}

It is concluded, therefore, that it is possible to develop a sustainable education from the classroom in an interdisciplinary perspective, and at the same time to promote the student's contact with scientific research, thus raising the emergence of a new researchers' generation. However, it is understood that it is through dialogue, in communion with all those interested, that one seeks to have more knowledge. Thus, language and thinking in a reality, dialectically, constitute a "liberating education", according to Freire (2016), that is, with a good dialogue, learning becomes more efficient, along with field research, practical classes, contact with diverse perceptions of the world and different ways of apprehending sustainable mechanisms; for example, learning favors a more pleasant and even ecological environment. 
Thus, by engaging with a pedagogical methodology (teaching and learning) together with social work, a practical education is made, a form of learning that leads to the construction of knowledge through the experiences experienced by the students, as well as by all those involved. In addition, it is possible to design mechanisms and educational and operational projects to raise awareness, preserve and even restructure a degraded environment.

It has been realized, therefore, that environmental education is an urgent measure and that the school can be configured as a very important tool in the formation of new mentalities and attitudes towards the environment, especially with respect to water and its uses as well as being the locus for the emergence of new scientists. However, it is necessary to take small initiatives, get out of the "confinement" of the classrooms, and overcome the barriers of the comfort zone. It is necessary, therefore, to break paradigms of learning, using the school environment itself as a laboratory of practical activities, valuing the diverse knowledge of the students and promoting the sociability of these knowledge from the school environment itself, from a perspective of thinking the whole to from place to place.

This experience, which was carried out by the students and teachers of the aforementioned school unit, showed that it was possible to develop an effective environmental education, without, however, requiring the expenditure of great efforts and enormous resources. However, it is necessary to have initiatives to promote a constant dialogue among the different knowledge areas. They are simple actions, but of great importance for the current environmental context that the planet earth and its inhabitants are experiencing.

\section{Conflicts of Interest}

The authors declare no conflicts of interest regarding the publication of this paper.

\section{References}

Brasil Ministério da Educação e do Desporto/Secretaria de Educação Fundamental (1998). Parâmetros curriculares nacionais História e Geografia. Brasília: MEC/SEF.

Falcão Sobrinho, J., Araújo, A. P. M., Falcão, I. L. C., \& Falcão, Í. L. C. (2017). Natureza, meio ambeinte e a teoria geral dos sistemas bases ambientais. Econômicas e Jurídicas, $8,104-125$.

Falcão Sobrinho, J., Costa Falcão, C. L., Silva, E. V., \& Mendes, M. V. R. (2018). Cearense Semi-Alarm Plate Tiles: The Case of IPU, Ceará, Brazil. Modern Environmental Science and Engineering, 4, 522-529. https://doi.org/10.15341/mese(2333-2581)/06.04.2018/005

Freire, P. (2016). Pedagogia do Oprimido. Rio de Janeiro: Paz e Terra.

Guimarães, M. (1995). A dimensão ambiental na educação (104 p). Campinas: Papirus.

Lima, A. M. M. (2007). Conceito de meio ambiente. http://ambientedomeio.com/2011/032/5/conceito-de-meio-ambiente/

Lindner, E. L. (2012). Refletindo sobre o ambiente. In: Educação Ambiental: Da teoria à prática. Org: Cassiano Pamplona Lisboa; Eunice Aita Isaia Kindel; Alexandre José 
Diehl Krob. Porto Alegre: Mediação.

Lopes, L. G. N., Silva, A. G., \& Goulart, A. C. O. (2015). A Teoria Geral do Sistema e suas aplicações nas ciências naturais. http://www.naturezaonline.com.br/natureza/conteudo/pdf/01_LopesLGNetal_1-5.pdf

Minc, C. (2005). Ecologia e cidadania/Carlos Minc(2nd ed.). São Paulo: Moderna.

Quintella Baptista, N. E., \& Campos, C. H. (2013). Educação contextualizada para aconvivência com o Semiárido. In I. L. Conti, \& E. O. Schroeder (Eds.), Convivência com o Semiárido Brasileiro: Autonomia e protagonismo social (pp. 83-96). Brasília: IABS.

Silva, F. E. R., Falcão Sobrinho, José, Silva, E. V., \& Costa Falcão, C. L. (2017). Escola sustentável no ambiente semiárido. In G. Seabra (Org.), Educação ambiental: Ensino, pesquisa e práticas aplicadas (1st ed., Vol. 1, pp. 1134-1145). Ituiutaba: Barlavento. 